\title{
Kinetics and Mechanism of the Aminolysis of Aryl N-Benzyl Thiocarbamates in Acetonitrile
}

\author{
Hyuck Keun Oh \\ Department of Chemistry, Research Institute of Physics and Chemistry, Chonbuk National University, \\ Chonju 561-756, Korea.E-mail: ohkeun@chonbuk.ac.kr \\ Received October 18, 2010, Accepted November 2, 2010
}

\begin{abstract}
The aminolysis reactions of phenyl N-benzyl thiocarbamate with benzylamines in acetonitrile at $50.0{ }^{\circ} \mathrm{C}$ are investigated. The reactions are first order in both the amine and the substrate. Under amine excess, pseudo-first coefficient $\left(k_{\mathrm{obs}}\right)$ are obtained, plot of $k_{\mathrm{obs}} v s$ free amine concentration are linear. The signs of $\rho_{\mathrm{XZ}}(<0)$ are consistent with concerted mechanism. Moreover, the variations of $\rho_{\mathrm{X}}$ and $\rho_{\mathrm{Z}}$ with respect to the sustituent in the substrate and large $\rho_{\mathrm{XZ}}$ value indicate that the reactions proceed concerted mechanism. The normal kinetic isotope effects $\left(k_{\mathrm{H}} / k_{\mathrm{D}}=1.3 \sim\right.$ 1.5) involving deuterated benzylamine nucleophiles suggest a hydrogen-bonded, four-centered-type transition state. The activation parameters, $\Delta H^{+}$and $\Delta S^{t}$, are consistent with this transition state structure.
\end{abstract}

Key Words: Nucleophilic substitution, Aryl N-benzyl thiocarbamates, Cross-interaction constant, Kinetic isotope effects, Concerted mechanism

\section{Introduction}

Although the aminolysis mechanism of aryl esters ${ }^{1}(\mathbf{1})$ and carbonate $^{2}(2)$ have been investigated extensively, reports on the aminolysis mechanism of carbamates (3) are scares. These three classes of carbonyl compounds differ only in the acyl part, $\mathrm{R}, \mathrm{RO}$ and $\mathrm{RNH}$, where $\mathrm{R}$ is alkyl or aryl, with a similar phenoxy leaving group, OAr. The aminolysis mechanism of the carbamates is therefore expected to be similar to the relatively well known aminolysis mechanisms of the esters 1 and carbonates 2. Shawali et al. ${ }^{3}$ proposed a stepwise mechanism with rate-limiting breakdown of a tetrahedral intermediate, $\mathrm{T}^{ \pm}$, for the reactions of aryl $\mathrm{N}$-arylcarbamates, $\mathrm{R}=\mathrm{Ar}$ in $\mathbf{3}$, with butylamine in dioxane. The stepwise of 2 through a tetrahedral intermediate, however, shifts to a concerted process when the leaving group is changed to a thiophenoxide ${ }^{4}(\mathrm{EtOC}(=\mathrm{O}) \mathrm{SAr})$ instead of a phenoxide ( $\mathrm{OAr}$ ). The push provided by an EtO group to expel ${ }^{-} \mathrm{SAr}$ in $\mathrm{T}^{ \pm}$is now strong enough to make the intermediate so unstable that the intermediate cannot exist. In view of the similar strong push expected from a $\mathrm{PhCH}_{2} \mathrm{NH}$ group to expel the ${ }^{-} \mathrm{SAr}$ group in $\mathrm{T}^{ \pm}$, it is of interest to see whether the aminolysis mechanism of the thiol analogue of aryl N-benzyl thiocarbamates also shifts to a concerted mechanism or not.

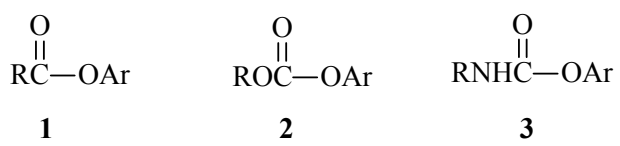

In order to pursue further the mechanistic similarities between carbamates and carbonates, we carried out kinetic studies on the aminolysis of aryl N-benzyl thiocarbamates $\left(\mathrm{C}_{6} \mathrm{H}_{5} \mathrm{CH}_{2} \mathrm{NHC}\right.$ $\left.(=\mathrm{O}) \mathrm{SC}_{6} \mathrm{H}_{4} \mathrm{Z}\right)$ with benzylamines in acetonitrile, eq 1 . The primary purpose of this work is to establish the aminolysis mechanism for eq 1 and to examine the effect of the nonleaving group, $\mathrm{C}_{6} \mathrm{H}_{5} \mathrm{CH}_{2} \mathrm{NH}-$, on the mechanism. We varied substituents in the nucleophile $(\mathrm{X})$ and leaving group $(\mathrm{Z})$ and the rate constants, $k_{2}$, are subjected to a multiple regression analysis to

$$
\begin{aligned}
& \underset{\mathrm{PhCH}_{2} \mathrm{NHC}}{\stackrel{\mathrm{O}}{\text { II }}}-\mathrm{SC}_{6} \mathrm{H}_{4} \mathrm{Z}+\mathrm{XC}_{6} \mathrm{H}_{4} \mathrm{CH}_{2} \mathrm{NH}_{2} \underset{50.0{ }^{\circ} \mathrm{C}}{\stackrel{\mathrm{MeCN}}{\longrightarrow}} \\
& \stackrel{\text { II }}{\stackrel{\mathrm{In}}{\mathrm{PhCH}_{2} \mathrm{NHC}}-\mathrm{NHCH}_{2} \mathrm{C}_{6} \mathrm{H}_{4} \mathrm{X}}+\mathrm{HSC}_{6} \mathrm{H}_{4} \mathrm{Z}
\end{aligned}
$$

determine the cross-interaction constant ${ }^{4}, \rho_{\mathrm{Xz}}$ in eq 2 . For a concerted mechanism the sign of $\rho_{\mathrm{XZ}}$ was found to be negative ${ }^{4}$ and the reactivity-selectivity principle (RSP) failed. ${ }^{5}$

$$
\begin{aligned}
& \log \left(k_{\mathrm{XZ}} / k_{\mathrm{HH}}\right)=\rho_{\mathrm{X}} \sigma_{\mathrm{X}}+\rho_{\mathrm{Z}} \sigma_{\mathrm{Z}}+\rho_{\mathrm{XZ}} \sigma_{\mathrm{X}} \sigma_{\mathrm{Z}} \\
& \rho_{\mathrm{XZ}}=\partial \rho_{\mathrm{Z}} / \partial \sigma_{\mathrm{X}}=\partial \rho_{\mathrm{Y}} / \partial \sigma_{\mathrm{Z}}
\end{aligned}
$$

\section{Results and Discussion}

The reactions of aryl N-benzylthiocarbamates $\left(\mathrm{C}_{6} \mathrm{H}_{5} \mathrm{CH}_{2} \mathrm{NHC}\right.$ $\left.(=\mathrm{O}) \mathrm{SC}_{6} \mathrm{H}_{4} \mathrm{Z}\right)$ with benzylamines follow a clean second-order kinetics, eq 3.

$$
\begin{aligned}
& \text { Rate } \left.=k_{\text {obs }} \text { [substrate }\right] \\
& k_{\text {obs }}=k_{2} \text { [benzylamine] }
\end{aligned}
$$

Unlike in the aminolysis of aryl N-phenylcarbamate, ${ }^{6}$ no base catalysis by the amine was noted. The rate constants, $k_{2}$, determined are summarized in Table 1 together with the selectivity parameters, $\rho_{\mathrm{X}}, \beta_{\mathrm{X}}, \rho_{\mathrm{Z}}$, and $\beta_{\mathrm{Z}}$. For the determination of $\beta_{\mathrm{X}}$ $\left(\beta_{\text {nuc }}\right)$, the $\mathrm{p} K_{\mathrm{a}}$ values of benzylamines in $\mathrm{H}_{2} \mathrm{O}$ are used. This procedure was found to be reliable since the $\mathrm{p} K_{\mathrm{a}}$ values in $\mathrm{MeCN}$ and in $\mathrm{H}_{2} \mathrm{O}$ varies in parallel, albeit the absolute values are different. ${ }^{7}$ For the $\beta_{Z}\left(\beta_{\text {eg }}\right)$ values, a factor of 0.62 was multiplied to all the $\beta_{\mathrm{Z}}$ values determined using the $\mathrm{p} K_{\mathrm{a}}\left(\mathrm{H}_{2} \mathrm{O}\right)$ values. ${ }^{7}$ The rates are substantially slower for the aminolysis of aryl N-benzylthiocarbamates $\left(k_{2}=5.84 \times 10^{-3} \mathrm{M}^{-1} \mathrm{~s}^{-1}\right.$ at $50.0{ }^{\circ} \mathrm{C}$ with $\mathrm{X}=\mathrm{H}$ and $\mathrm{Z}=\mathrm{H}$ ) than for the corresponding reactions of aryl N-ethylthiocarbamates $\left(k_{2}=7.36 \times 10^{-3} \mathrm{M}^{-1}\right.$ 
Table 1. The Second Order Rate Constants, $k_{2}\left(10^{2} \mathrm{dm}^{3} \mathrm{~mol}^{-1} \mathrm{~s}^{-1}\right)$ for the Reactions of Z-Aryl N-Benzyl Thiocarbamates with X-Benzylamines in Acetonitrile at $50.0^{\circ} \mathrm{C}$

\begin{tabular}{|c|c|c|c|c|c|c|}
\hline \multirow{2}{*}{$\mathrm{X}$} & \multicolumn{4}{|c|}{$\mathrm{Z}$} & \multirow{2}{*}{$\rho_{\mathrm{Z}}^{a}$} & \multirow{2}{*}{$\beta_{\mathrm{Z}}^{b}$} \\
\hline & $p-\mathrm{Me}$ & $\mathrm{H}$ & $p-\mathrm{Cl}$ & $p-\mathrm{Br}$ & & \\
\hline$p$-OMe & $\begin{array}{l}0.316 \\
0.221^{c} \\
0.152^{d}\end{array}$ & 2.07 & 33.9 & $\begin{array}{l}37.6 \\
25.5^{c} \\
17.5^{d}\end{array}$ & $5.17 \pm 0.04$ & $-2.18 \pm 0.09$ \\
\hline$p-\mathrm{Me}$ & 0.224 & 1.39 & 20.2 & 22.4 & $4.98 \pm 0.03$ & $-2.10 \pm 0.09$ \\
\hline $\mathrm{H}$ & 0.126 & 0.584 & 8.16 & 8.32 & $4.61 \pm 0.06$ & $-1.96 \pm 0.03$ \\
\hline$p-\mathrm{Cl}$ & $\begin{array}{l}0.0557 \\
0.0384^{c} \\
0.0265^{d}\end{array}$ & 0.248 & 2.81 & $\begin{array}{l}2.87 \\
2.01^{c} \\
1.38^{d}\end{array}$ & $4.32 \pm 0.05$ & $-1.84 \pm 0.05$ \\
\hline$m-\mathrm{Cl}$ & 0.0314 & 0.135 & 1.22 & 1.24 & $4.02 \pm 0.03$ & $-1.71 \pm 0.07$ \\
\hline$\rho_{\mathrm{X}}^{a}$ & $-1.56 \pm 0.01$ & $-1.85 \pm 0.03$ & $-2.22 \pm 0.02$ & $-2.29 \pm 0.03$ & \multirow{2}{*}{\multicolumn{2}{|c|}{$\rho_{\mathrm{XZ}}^{e}=-1.75$}} \\
\hline$\beta_{\mathrm{X}}^{f}$ & $1.57 \pm 0.02$ & $1.87 \pm 0.04$ & $2.24 \pm 0.04$ & $2.31 \pm 0.04$ & & \\
\hline
\end{tabular}

${ }^{a}$ The $\sigma$ values were taken from ref. 19a. Correlation coefficients were better than 0.998 in all cases. ${ }^{b}$ The $\mathrm{p} K_{\mathrm{a}}$ values were taken from ref. 19b. Correlation coefficients were better than 0.998 in all cases. ${ }^{c}$ At $30{ }^{\circ} \mathrm{C} .{ }^{d}$ At $20^{\circ} \mathrm{C} .{ }^{e}$ alculated by a multiple regression analysis using eq $2 \mathrm{a} . \mathrm{r}=0.999, \mathrm{n}=20$ and $\mathrm{F}_{\text {calc }}$ $=1410\left(\mathrm{~F}_{\mathrm{tab}}=10.66\right.$ at the $99.9 \%$ confidence level $) .{ }^{f}$ The $\mathrm{p} K_{\mathrm{a}}$ values were taken from ref. $19 \mathrm{c}$. Correlation coefficients were better than 0.997 in all cases. For $\mathrm{X}=p-\mathrm{CH}_{3} \mathrm{O}$ an extrapolated value of $\mathrm{p} K_{\mathrm{a}}=9.64$ was used.

$\mathrm{s}^{-1}$ at $30.0^{\circ} \mathrm{C}$ with $\mathrm{X}=\mathrm{H}$ and $\left.\mathrm{Z}=\mathrm{H}\right) .{ }^{8 \mathrm{a}}$ This slower rate found with N-benzyl relative to N-ethyl analog can be attributed to the weaker push provided by the benzylamino $\left(\mathrm{C}_{6} \mathrm{H}_{5} \mathrm{CH}_{2} \mathrm{~N}: \sigma_{\mathrm{p}}{ }^{+}\right.$ is -0.28$)^{5}$ than ethylamino (EtNH: $\sigma_{\mathrm{p}}{ }^{+}$is -0.31$)^{5}$ group to expel the leaving group from a tetrahedral structure ${ }^{8 \mathrm{a}}$ which may be either an intermediate $\mathrm{T}^{ \pm}$or a transition state, $\mathrm{T}^{ \pm}$(TS).

Interestingly, as we move up to the stronger electron donating group, $\mathrm{EtO}$ and $\mathrm{PhNH}$, a mechanistic change occurs from stepwise with phenoxide $(\mathrm{OAr})^{6,9 a}$ to concerted with thiophenoxide leaving group ${ }^{8 b, 96}$ ( $(\mathrm{SAr})$. This is because the thiophenoxides are better leaving groups than phenoxides, since the $\sigma^{*}{ }_{\mathrm{C}-\mathrm{S}}$ orbital is lower than the $\sigma^{*} \mathrm{C}$-o level and hence is a better electron acceptor and is readily broken compared to the $\mathrm{C}-\mathrm{O}$ bond. For example, the aminolysis of O-ethyl aryl carbonates with benzylamines $^{9 \mathrm{a}}$ in $\mathrm{MeCN}$ is stepwise with rate-limiting breakdown of $\mathrm{T}^{ \pm}\left(\beta_{\mathrm{X}}=2.4\right.$ for $\mathrm{Z}=4-\mathrm{NO}_{2}$, and $\left.\rho_{\mathrm{XZ}}=1.35\right)$ but the corresponding reaction of O-ethyl arylthiolcarbonate ${ }^{10 \mathrm{~b}}$ is concerted $\left(\beta_{\mathrm{X}}=0.6\right.$ for $\mathrm{Z}=4-\mathrm{NO}_{2}$, and $\left.\rho_{\mathrm{XZ}}=-0.47\right)$. Likewise the aminolysis of $\mathrm{N}$-phenyl aryl carbamates with benzylamines ${ }^{9 \mathrm{a}}$ in $\mathrm{MeCN}$ is stepwise $\left(\beta_{\mathrm{X}}=1.3, \rho_{\mathrm{XZ}}=+1.10\right)$ but that of thiocarbamate ${ }^{8 \mathrm{~b}}$ analogs react by a concerted mechanism $\left(\beta_{\mathrm{X}}=1.3, \rho_{\mathrm{XZ}}=-0.63\right)$.

Benzylamines are reported to strongly destabilize the intermediate, ${ }^{4} \mathrm{~T}^{ \pm}$, due to their powerful nucleofugality from $\mathrm{T}^{ \pm}$, as the order of the increasing rate of expulsion shows: ${ }^{5,10}$ pyridines $<$ anilines $<$ secondary alicyclic amines $<$ quinuclidines $<$ benzylamines. These three factors, the less polar solvent, $\mathrm{MeCN}$, than water, a carbonyl rather than a thiocarbonyl compound, and benzylamines used in the present work are all conducive to the concerted mechanism.

Further important mechanistic criteria for the concerted with aryl N-benzylthiocarbamates rather than the stepwise (as with aryl phenylcarbamate) is that the sign of cross-interaction constant $\rho_{\mathrm{Xz}}$ is negative for aryl N-benzylthiocarbamates (rather than positive as with aryl phenylcarbamate) and the RSP fails with aryl N-benzylthiocarbamates. ${ }^{5,7}$ The stepwise mechanism is not favored for the present reactions, since for the stepwise aminolysis of esters, carbonates and carbamates, the sign of $\rho_{\mathrm{XZ}}$ is positive and the RSP holds. ${ }^{5,7}$

The magnitude of $\beta_{\mathrm{X}}$ is, however, large $\left(\beta_{\mathrm{X}} \cong 1.6 \sim 2.3\right)$ which is normally considered to indicate a stepwise reaction. ${ }^{11}$ For concerted aminolysis reactions, the $\beta_{\mathrm{X}}$ values were found to range from $0.4 \sim 0.8 .{ }^{12}$ It is, however, well known that the large magnitude of the Brönsted slope alone is not sufficient to decide the aminolysis mechanism as stepwise. Jencks and coworkers reported concerted acyl transfer reactions with large $\beta_{\mathrm{X}}$ values, $\beta_{\mathrm{X}}=0.6 \sim 0.9$ for the reactions of phenyl formates with substituted $\mathrm{O}$-chlorophenolate anions ${ }^{13}$ and $\beta_{\mathrm{X}}=0.7 \sim 1.0$ for the reactions of a series of nucleophilic reagents with substituted $\mathrm{N}$-acetylpyridinium ions. ${ }^{14}$ Williams and coworkers ${ }^{15}$ reported even larger $\beta_{\mathrm{X}}$ values $\left(\beta_{\mathrm{X}}=1.3\right.$ and 1.6) for the concerted acyl transfer reactions. Thus the large $\beta_{\mathrm{X}}$ values observed in the present work may be taken as an indicative of a stepwise mechanism, but can not provide a conclusive evidence for a stepwise mechanism.

The kinetic isotope effects (Table 2) involving deuterated nucleophile, $\mathrm{XC}_{6} \mathrm{H}_{4} \mathrm{CH}_{2} \mathrm{ND}_{2}$, are normal $\left(k_{\mathrm{H}} / k_{\mathrm{D}}>1.0\right)$ suggesting a possibility of forming hydrogen-bonded four-center type TS $(4)^{16}$ as has often been proposed. Since no base catalysis was found (the rate law is first order with respect to [benzylamine], eq 3). the proton transfer occurs concurrently with the rate-limiting expulsion of $\mathrm{ArO}^{-}$in the TS but not catalyzed by benzylamine. The consumption of proton by the excess benzylamine should therefore take place in a subsequent rapid step.

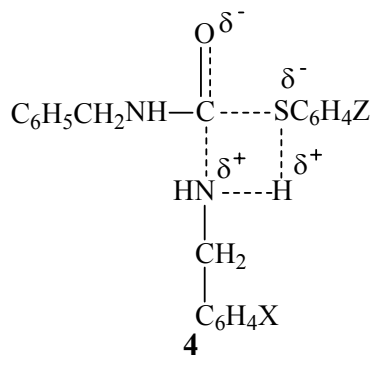


Table 2. The Kinetic Isotope Effects for the Reactions of Z-phenyl $\mathrm{N}$-Benzyl Thiocarbamates with X-Benzylamines in Acetonitrile at $50.0{ }^{\circ} \mathrm{C}$

\begin{tabular}{lcccc}
\hline \multicolumn{1}{c}{$\mathrm{X}$} & $\mathrm{Z}$ & $\begin{array}{c}k_{\mathrm{H}} \times 10^{2} \\
\left(\mathrm{dm}^{3} \mathrm{~mol}^{-1} \mathrm{~s}^{-1}\right)\end{array}$ & $\begin{array}{c}k_{\mathrm{D}} \times 10^{2} \\
\left(\mathrm{dm}^{3} \mathrm{~mol}^{-1} \mathrm{~s}^{-1}\right)\end{array}$ & $k_{\mathrm{H}} / k_{\mathrm{D}}$ \\
\hline$p$-OMe & $p-\mathrm{Me}$ & $0.316 \pm 0.004$ & $0.234 \pm 0.002$ & $1.35 \pm 0.02^{a}$ \\
$p$-OMe & $\mathrm{H}$ & $2.07 \pm 0.06$ & $1.46 \pm 0.02$ & $1.41 \pm 0.03$ \\
$p-\mathrm{OMe}$ & $p-\mathrm{Cl}$ & $33.9 \pm 0.7$ & $23.6 \pm 0.4$ & $1.47 \pm 0.02$ \\
$p$ - $\mathrm{OMe}$ & $p-\mathrm{Br}$ & $37.6 \pm 0.9$ & $24.4 \pm 0.5$ & $1.54 \pm 0.02$ \\
$p-\mathrm{Cl}$ & $p-\mathrm{Me}$ & $0.0557 \pm 0.0003$ & $0.0421 \pm 0.0002$ & $1.32 \pm 0.01$ \\
$p-\mathrm{Cl}$ & $\mathrm{H}$ & $0.248 \pm 0.002$ & $0.178 \pm 0.001$ & $1.39 \pm 0.02$ \\
$p-\mathrm{Cl}$ & $p-\mathrm{Cl}$ & $2.81 \pm 0.04$ & $1.92 \pm 0.02$ & $1.46 \pm 0.03$ \\
$p-\mathrm{Cl}$ & $p-\mathrm{Br}$ & $2.87 \pm 0.05$ & $1.90 \pm 0.02$ & $1.51 \pm 0.02$ \\
\hline
\end{tabular}

${ }^{a}$ Standard deviations.

Table 3. Activation Parameters ${ }^{a}$ for the Reactions of Z-Pphenyl N-benzyl Thiocarbamates with X-Benzylamines in Acetonitrile

\begin{tabular}{llcc}
\hline \multicolumn{1}{c}{$\mathrm{X}$} & $\mathrm{Z}$ & $\Delta H^{*} / \mathrm{kcal} \mathrm{mol}^{-1}$ & $-\Delta S^{\star} / \mathrm{cal} \mathrm{mol}^{-1} \mathrm{~K}^{-1}$ \\
\hline$p$-OMe & $p-\mathrm{Me}$ & 4.6 & 51 \\
$p$-OMe & $p-\mathrm{Br}$ & 4.6 & 41 \\
$p-\mathrm{Cl}$ & $p-\mathrm{Me}$ & 4.5 & 47 \\
$p-\mathrm{Cl}$ & $p-\mathrm{Br}$ & 4.5 & 46 \\
\hline
\end{tabular}

${ }^{a}$ Calculated by the Eyring equation. The maximum errors calculated (by the method of Wiberg, K. B. ${ }^{20}$ ) are $\pm 1.1 \mathrm{kcal} \mathrm{mol}^{-1}$ and \pm 4 e.u. for $\Delta H^{7}$ and $\Delta S^{\neq}$, respectively.

The low activation enthalpies, $\Delta H^{\ddagger}$, and highly negative activation entropies, $\Delta S^{\ddagger}$, (Table 3 ) are also in line with the proposed TS. Especially, the $\Delta H^{\ddagger}$ values are somewhat lower and the $\Delta S^{\ddagger}$ values are higher negative values than other aminolysis systems. ${ }^{17}$ The expulsion of $\mathrm{ArO}^{-}$anion in the rate determining step (an endoergic process) is assisted by the hydrogen-bonding with an amino hydrogen of the benzylammonium ion within the intermediate, $\mathrm{T}^{ \pm}$. This will lower the $\Delta H^{\ddagger}$ value, but the TS becomes structured and rigid (low entropy process) which should lead to a large negative.

In summary, the aminolysis reactions of phenyl N-benzyl thiocarbamate with benzylamines in acetonitrile at $50.0^{\circ} \mathrm{C}$ are investigated. The signs of $\rho_{\mathrm{XZ}}(<0)$ are consistent with concerted mechanism. Moreover, the variations of $\rho_{\mathrm{X}}$ and $\rho_{\mathrm{Z}}$ with respect to the sustituent in the substrate and large $\rho_{\mathrm{XZ}}$ value indicate that the reactions proceed concerted mechanism. The normal kinetic isotope effects $\left(k_{\mathrm{H}} / k_{\mathrm{D}}=1.3 \sim 1.5\right)$ involving deuterated benzylamine nucleophiles suggest a hydrogen-bonded, four-centered-type transition state. The activation parameters, $\Delta H^{+}$and $\Delta S^{*}$, are consistent with this transition state structure.

\section{Experimental Section}

Materials. GR grade acetonitrile was used after three distillations. GR grade benzylamine nucleophiles were used after recrystallization.

\section{Substrates.}

Phenyl N-Benzyl Thiocarbamate: A solution of phenol (0.01 $\mathrm{mol})$ in dry toluene $(10 \mathrm{~mL})$ was added to a solution of benzyl isocyanate $(0.01 \mathrm{~mol})$. A catalytic quantity $(0.5 \mathrm{~mL})$ of pyridine was added and the solution refluxed for $2 \mathrm{~h}$. On evapolation of the solvent in vacuo, the thiocarbamate precipitated and was recrystallized from chloroform-pentane. The other substituted phenyl N-benzyl thiocarbamates were prepared in an analogous manner and recrystallized from chloroform-pentane. The substrates synthesized were confirmed by spectral and elemental analysis as follows.

$\mathbf{C}_{6} \mathbf{H}_{5} \mathbf{C H}_{2} \mathbf{N H C}(=\mathbf{O}) \mathbf{S C}_{6} \mathbf{H}_{4}-\boldsymbol{p}-\mathbf{C H}_{3}$ : $\operatorname{mp~} 130-132{ }^{\circ} \mathrm{C} ;{ }^{1} \mathrm{H}$ NMR $\left(400 \mathrm{MHz}, \mathrm{CDCl}_{3}\right) \delta 2.44\left(3 \mathrm{H}, \mathrm{s}, \mathrm{CH}_{3}\right), 4.49\left(2 \mathrm{H}, \mathrm{d}, \mathrm{CH}_{2}\right), 6.2$ (1H, s, NH), 7.23-7.48 (9H, m, $\left.\mathrm{C}_{6} \mathrm{H}_{5}, \mathrm{C}_{6} \mathrm{H}_{4}\right) ;{ }^{13} \mathrm{C} \mathrm{NMR}(100.4$ $\left.\mathrm{MHz}, \mathrm{CDCl}_{3}\right) \delta 166.6,140.1,137.5,135.4,130.2,128.6,127.4$, 124.7, 45.2, 21.4; $v_{\max }(\mathrm{KBr}), 3448(\mathrm{NH}), 3045-3201(\mathrm{CH}), 2835$ (CH, aromatic), $1647(\mathrm{C}=\mathrm{O}), 745(\mathrm{C}-\mathrm{S})$; $\mathrm{MS} \mathrm{m} / z 257\left(\mathrm{M}^{+}\right)$. Anal. Calcd for $\mathrm{C}_{15} \mathrm{H}_{15} \mathrm{NOS}$ : C, 70.0; H, 5.91. Found; C, 69.9; H, 5.93.

$\mathbf{C}_{6} \mathbf{H}_{5} \mathbf{C H}_{2} \mathbf{N H C}(=\mathbf{O}) \mathbf{S C}_{6} \mathbf{H}_{5}: \mathrm{mp} 118-120{ }^{\circ} \mathrm{C} ;{ }^{1} \mathrm{H}$ NMR (400 $\left.\mathrm{MHz}_{2} \mathrm{CDCl}_{3}\right) \delta 45.4\left(2 \mathrm{H}, \mathrm{d}, \mathrm{CH}_{2}\right), 6.4(1 \mathrm{H}, \mathrm{s}, \mathrm{NH}), 7.25-7.60$ $\left(10 \mathrm{H}, \mathrm{m}, \mathrm{C}_{6} \mathrm{H}_{5}, \mathrm{C}_{6} \mathrm{H}_{5}\right) ;{ }^{13} \mathrm{C} \mathrm{NMR}\left(100.4 \mathrm{MHz}, \mathrm{CDCl}_{3}\right) \delta 166.1$, $137.4,135.4,139.6,129.4,128.6,127.6,127.5,45.4 ; v_{\max }(\mathrm{KBr})$, $3449(\mathrm{NH}), 3043-3203(\mathrm{CH}), 2845(\mathrm{CH}$, aromatic), $1647(\mathrm{C}=\mathrm{O})$, 749 (C-S); MS m/z $243\left(\mathrm{M}^{+}\right)$. Anal. Calcd $\mathrm{C}_{14} \mathrm{H}_{13} \mathrm{NOS}$ : C, 69.1; H, 5.41. Found; C, 69.3; H, 5.42.

$\mathbf{C}_{6} \mathbf{H}_{5} \mathbf{C H}_{2} \mathbf{N H C}(=\mathbf{O}) \mathbf{S C}_{6} \mathbf{H}_{4}-\boldsymbol{p}$-Cl: $\mathrm{mp} 150-152{ }^{\circ} \mathrm{C} ;{ }^{1} \mathrm{H}$ NMR $\left(400 \mathrm{MHz}, \mathrm{CDCl}_{3}\right) \delta 4.52\left(2 \mathrm{H}, \mathrm{d}, \mathrm{CH}_{2}\right), 6.5(1 \mathrm{H}, \mathrm{s}, \mathrm{NH}), 7.27-$ $7.52\left(9 \mathrm{H}, \mathrm{m}, \mathrm{C}_{6} \mathrm{H}_{5}, \mathrm{C}_{6} \mathrm{H}_{4}\right) ;{ }^{13} \mathrm{C} \mathrm{NMR}\left(100.4 \mathrm{MHz}, \mathrm{CDCl}_{3}\right) \delta$ 165.3, 137.2, 136.5, 135.9, 139.4, 129.2, 128.7, 127.7, 45.5; $v_{\max }(\mathrm{KBr}), 3448(\mathrm{NH}), 3042-3202(\mathrm{CH}), 2840(\mathrm{CH}$, aromatic), $1650(\mathrm{C}=\mathrm{O}), 748(\mathrm{C}-\mathrm{S})$; MS m/z $277\left(\mathrm{M}^{+}\right)$. Anal. Calcd $\mathrm{C}_{14} \mathrm{H}_{12}$ CINOS: C, 60.5; H, 4.41. Found; C, 60.7; H, 4.43.

$\mathbf{C}_{6} \mathbf{H}_{5} \mathbf{C H}_{2} \mathbf{N H C}(=\mathbf{O}) \mathbf{S C}_{6} \mathbf{H}_{4}-\boldsymbol{p}$-Br: $\mathrm{mp} 114-116{ }^{\circ} \mathrm{C} ;{ }^{1} \mathrm{H}$ NMR $\left(400 \mathrm{MHz} \mathrm{CDCl}_{3}\right) \delta 4.49\left(2 \mathrm{H}, \mathrm{d}, \mathrm{CH}_{2}\right), 6.1(1 \mathrm{H}, \mathrm{s}, \mathrm{NH}), 7.27-$ $7.56\left(9 \mathrm{H}, \mathrm{m}, \mathrm{C}_{6} \mathrm{H}_{5}, \mathrm{C}_{6} \mathrm{H}_{4}\right) ;{ }^{13} \mathrm{C}$ NMR $\left(100.4 \mathrm{MHz} \mathrm{CDCl}_{3}\right) \delta$ 165.1, 136.7, 132.4, 132.1, 129.3, 128.7, 127.8, 127.6, 124.2, 45.6 ; $v_{\max }(\mathrm{KBr}), 3448(\mathrm{NH}), 3042-3206(\mathrm{CH}), 2843(\mathrm{CH}$, aromatic), $1645(\mathrm{C}=\mathrm{O}), 750(\mathrm{C}-\mathrm{S})$; MS $m / z 322\left(\mathrm{M}^{+}\right)$. Anal. Calcd $\mathrm{C}_{14} \mathrm{H}_{12}$ BrNOS: C, 52.2; H, 3.80. Found; C,52.4; H, 3.82.

Kinetic Measurement. Rates were measured conductometrically in acetonitrile. The conductivity bridge used in this work was a homemade computer-automatic A/D converter conductivity bridge. Pseudo-first-order rate constants, $k_{\text {obsd, }}$, were determined by the Guggenheim method ${ }^{18}$ with large excess of pyridine. Second order rate constants, $k_{\mathrm{N}}$, were obtained from the slope of a plot of $k_{\text {obsd }} v s$. [BA] with more than five concentrations of benzylamine. The $k_{2}$ values in Table 1 are the averages of more than three runs and were reproducible to within $\pm 3 \%$.

Product Analysis. The substrate $p$-bromophenyl N-benzyl thiocabamate $(0.01$ mole) was reacted with excess $p$-methylbenzylamine $(0.1$ mole) with stirring for more than 15 halflives at $50.0{ }^{\circ} \mathrm{C}$ in acetonitrile $(c a .200 \mathrm{~mL})$ and the products were isolated by evaporating the solvent under reduced pressure. The product mixture was subjected to column chromatography (silica gel, $20 \%$ ethyl acetate- $n$-hexane). Analysis of the product gave the following results.

$\mathbf{C}_{6} \mathbf{H}_{5} \mathbf{C H}_{2} \mathbf{N H C}(=\mathbf{O}) \mathbf{N H C H}_{2} \mathbf{C}_{6} \mathbf{H}_{4}-\boldsymbol{p}-\mathbf{C H}_{3}: \mathrm{mp} 125-127^{\circ} \mathrm{C}$; ${ }^{1} \mathrm{H}$ NMR $\left(400 \mathrm{MHz}, \mathrm{CDCl}_{3}\right) \delta 2.40\left(3 \mathrm{H}, \mathrm{t}, \mathrm{CH}_{3}\right), 2.97(2 \mathrm{H}, \mathrm{s}$, $\left.-\mathrm{NH}-\mathrm{CH}_{2}\right), 4.68\left(2 \mathrm{H}, \mathrm{d}, \mathrm{CH}_{2}\right), 6.35(1 \mathrm{H}, \mathrm{s}, \mathrm{NH}), 7.19-7.28(9 \mathrm{H}$, $\left.\mathrm{m}, \mathrm{C}_{6} \mathrm{H}_{5}, \mathrm{C}_{6} \mathrm{H}_{4}\right) ;{ }^{13} \mathrm{C} \mathrm{NMR}\left(100.4 \mathrm{MHz}, \mathrm{CDCl}_{3}\right) \delta 157.8,138.9$, $135.8,132.4,129.1,128.5,127.4,127.3,121.1,44.5,21.1 ; v_{\max }$ 
(KBr), $3316(\mathrm{NH}), 3015(\mathrm{CH}$, aliphatic), 2931 (CH, aromatic), $1658(\mathrm{C}=\mathrm{O}), 631(\mathrm{C}-\mathrm{S})$; MS $m / z 240\left(\mathrm{M}^{+}\right)$. Anal. Calcd for $\mathrm{C}_{15} \mathrm{H}_{16} \mathrm{~N}_{2} \mathrm{O}$ : C, 75.0; H, 6.71. Found; C, 75.2; H, 7.69.

Acknowledgments. This paper was supported by research funds of Chonbuk National University in 2010.

\section{References}

1. (a) Gresser, M. J.; Jencks, W. P. J. Am. Chem. Soc. 1977, 99, 6963. (b) Castro, E. A.; Gil, F. J. J. Am. Chem. Soc. 1977, 99, 7611. (c) Castro, E. A.; Aliaga, M.; Campodonico, P. J.; Santos, J. G. J. Org. Chem. 2002, 67, 8911. (d) Castro, E. A.; Andajar, M.; Taro, A.; Santos, J. G. J. Org. Chem. 2003, 68, 3608, 5930. (e) Castro, E. A.; Cubillos, M.; Santos, J. G. J. Org. Chem. 2001, 66, 6000. (f) Bond, P. M.; Moodie, R. B. J. Chem. Soc. Perkin Trans. 2 1976, 679. (g) Shawali, A. S.; Harhash, A.; Sidky, M. M.; Hassanen, H. M.; Elkaabi, S. S. J. Org. Chem. 1986, 51, 3498.

2. (a) Satterthwait, A. C.; Jencks, W. P. J. Am. Chem. Soc. 1974, 96, 7018. (b) Oh, H. K.; Shin, C. H.; Lee, I. Bull. Korean Chem. Soc. 1995, 16, 657. (c) Oh, H. K.; Woo, S. Y.; Shin, C. H.; Park, Y. S.; Lee, I. J. Org. Chem. 1997, 62, 5780. (d) Um, I-H.; Kwon, H-J.; Kwon, D-S.; Park, J-Y. J. Chem. Res. 1995, 1801. (e) Um, I-H.; Choi, K-E.; Kwon, D-S. Bull. Korean Chem. Soc. 1990, 11, 362. (f) Castro, E. A.; Ureta, C. J. Chem. Soc. Perkin Trans 2 1991, 63. (g) Castro, E. A.; Areneda, C. A. Santos, J. G. J. Org. Chem. 1997, 62, 126. (h) Castro, E. A.; Ureta, C. J. Org. Chem. 1990, 55, 1676. (i) Castro, E. A.; Ureta, C. J. Org. Chem. 1989, 54, 1253. (j) Castro, E. A.; Santos, C. L. J. Org. Chem. 1985, 50, 3595.

3. Shawali, A. S.; Harhash, A.; Hassanee, H. M.; Alkaaabi, S. S. J. Org. Chem. 1986, 51, 3498

4. (a) Lee, I. Chem. Soc. Rev. 1990, 19, 317. (b) Lee, I. Adv. Phys. Org. Chem. 1992, 27, 57.

5. Lee, I.; Sung, D. D. Curr. Org. Chem. 2004, 8, 557.

6. Koh, H. J.; Kim, O. K.; Lee, H. W.; Lee, I. J. Phys. Org. Chem. $1997,10,725$.
7. (a) Coetzee, J. F. Prog. Phys. Org. Chem. 1967, 4, 45. (b) Lee, I.; Kim, C. K.; Han, I. S.; Lee, H. W.; Kim, W. K.; Kim, Y. B. J. Phys. Chem. B 1999, 103, 7302. (c) Spillane, W. J.; Hogan, G.; McGroth, P.; King, J.; Brack, C. J. Chem. Soc. Perkin trans. 2 1996, 2099. 8. (a) Oh, H. K.; Park, J. E,; Sung, D. D.; Lee, I. J. Org. Chem. 2004, 69, 9285. (b) Oh, H. K.; Park, J. E,; Sung, D. D.; Lee, I. J. Org. Chem. 2004, 69, 3150

9. (a) Koh, H. J.; Lee, J-W.; Lee, H. W.; Lee, I. Can, J. Chem. 1998, 76, 710. (b) Oh, H. K.; Lee, Y. H.; Lee, I. Int. J. Chem. Kinet. 2000, 32,131

10. (a) Castro, E. A.; Munoz, P.; Santos, J. G. J. Org. Chem. 1999, 64, 8298. (b) Lee, K. S.; Adhikary, K. K.; Lee, H. W; Lee, B. S.; Lee, I. Org. Biomol. Chem. 2003, 1, 1989.

11. Gresser, M. J.; Jencks, W. P. J. Am. Chem. Soc. 1977, 99, 6963.

12. (a) Castro, E. A.; Angel, M,; Arellano, D.; Santos, J. G. J. Org. Chem. 2001, 66, 6571. (b) Castro, E. A.; Leandro, L.; Millan, P.; Santos, J. G. J. Org. Chem. 1999, 64, 1953.

13. Stefanidas, D.; Cho, S.; Dhe-Paganon, S.; Jencks, W. P. J. Am. Chem. Soc. 1993, 115, 1650.

14. Fersht, A. R.; Jencks, W. P. J. Am. Chem. Soc. 1970, 92, 6963.

15. (a) Ba-Saif, S.; Luthra, A. K.; Williams, A. J. Am. Chem. Soc. 1989, 111, 2647. (b) Colthurst, M. J.; Nanni, M.; Williams, A. J. Chem. Soc. Perkin Trans. 2 1996, 2285.

16. (a) Pross, A. Adv. Phys. Org. Chem. 1997, 14, 69. (b) Lee, I.; Lee, H. W. Collect. Czech. Chem. Commun. 1999, 64, 1529.

17. Stefanidas, D.; Cho, S.; Dhe-Paganon, S.; Jencks, W. P. J. Am. Chem. Soc. 1993, 115, 1650.

18. (a) Guggenheim, E. A. Philos, Mag. 1926, 2, 538. (b) Oh, H. K.; Hong, S. K. Bull. Korean Chem. Soc. 2009, 30, 2453. (c) Jeong, K. S.; Oh, H. K. Bull. Korean Chem. Soc. 2008, 29, 1621.

19. (a) Hansch, C.; Leo, A.; Taft, R. W. Chem. Rev. 1991, 91, 165. (b) Bukingham, J. Dictionary of Organic Chemistry, 5th Ed.; Chapman and Hall: New York, 1982. (c) Streitwiser, A.; Heathcock, C. H. Introduction to Organic Chemistry, 3rd Ed.; Macmillan Publishing Co.: New York, 1989; p 693.

20. Wiberg, K. B. Physical Organic Chemistry; Wiley: New York, 1964, p 378. 